\author{
UC Irvine School of Law \\ Legal Studies Research Paper Series No. 2010-26 \\ Northwestern Public Law Research Paper No.10-87
}

\title{
Political Lawyers: The Structure of a National Network
}

\author{
Anthony Paik \\ anthony-paik@uiowa.edu \\ University of lowa \\ John P. Heinz \\ jheinz@abfn.org \\ American Bar Foundation \\ Ann Southworth \\ asouthworth@law.uci.edu \\ University of California, Irvine School of Law
}

The paper can be downloaded free of charge from SSRN at: 


\section{Political Lawyers: The Structure of a National Network* Anthony Paik, University of Iowa John P. Heinz, American Bar Foundation Ann Southworth, University of California, Irvine}

\footnotetext{
${ }^{*}$ The authors shared equally in this research.
} 


\section{ABSTRACT \\ Political Lawyers: The Structure of a National Network}

Some research on lawyers active in politics has found that the ties among them create networks in which a center or core of influential actors is surrounded by more peripheral participants. Other studies, however, found more segmented networks, sometimes lacking central players. This research examines the structure and determinants of political ties among 47 elite lawyers who served organizations prominent in fourteen national policy issues in 2004-2005. The analysis finds a network structure that resembles a rough circle with Republicans on one side and Democrats on the other. Lawyers affiliated with organizations representing a broad constellation of interests are closer to the center of the network, while those working for specialized or narrow causes tend to be located in the periphery. Ties are more dense among conservatives than among liberals. Lawyers who work as organizational leaders or managers are more likely to be near the center than are litigators. Central actors contribute larger amounts to election campaigns. The organized bar, especially the American Bar Association, appears to provide links between liberals and conservatives in one segment of the network. 
Given the prominence of lawyers in politics, one might expect scholarly attention to the networks of relationships among politically active lawyers. The structure of such networks and the positions of particular types of lawyers within them reflect and influence the power, resources, and missions of the organizations the lawyers serve (Southworth et al. 2010). Most research on the political networks of lawyers, however, has focused on specific contexts such as the Supreme Court bar (McGuire 1993) and lawyers working for conservative and libertarian organizations (Heinz et al. 2003; Paik et al. 2007). Little of the scholarly work has studied lawyers who represent diverse constituencies spanning the ideological spectrum (but see Laumann et al. 1985).

In this paper, we investigate the structure and determinants of networks among a broad set of lawyers involved in national policymaking. We examine the observed patterns of ties and assess the extent to which they reflect social and political cleavages - that is, the tendency for network ties to occur more frequently among lawyers sharing characteristics such as gender, party affiliation, legal roles, geographic region, and law school prestige. We also examine whether lawyers' positions in this network are related to political contributions in federal elections.

There is a considerable scholarly literature arguing that networks of relationships among elites active in American politics are characterized by clear hierarchies in which peripheral players surround a dense core of influential, well-connected actors. That work includes Mills’s The Power Elite (1956), William Domhoff's The Bohemian Grove (1974) and Who Rules America Now (1983), Gwen Moore’s “The Structure of a National Elite Network” (1979), and Michael Useem’s The Inner Circle (1984), among many other accounts. A survey of Washington lawyers and lobbyists in the 1980s, however, concluded 
that the relationships among them were divided into clusters or segments associated with distinct specialties defined by policy areas and clientele (Heinz et al., 1993). The core of the network structure was empty - $\underline{\text { i.e., }}$ there were few, if any, central actors. ${ }^{1}$ It is not clear whether the difference in findings was attributable to the research methods used, or time (i.e., historical effects), or differences among the populations studied. For example, the shared professional training of lawyers and the institutions of the legal profession, including the courts and the organized bar, may increase the likelihood of contact among members of that occupational “community.” A recent study of lawyers serving conservative political organizations found a stable core in the center of the network (Paik et al. 2007, Southworth 2008). However, because that finding could be attributable to the ideological affinity of the set of actors examined, a comparable analysis of lawyers representing a larger range of interest groups may be informative.

Several theoretical models of political networks have been posited. Knoke’s (1990) typology, shown in Figure 1, presents four hypothesized structures: centrally administered, polarized, bargaining, and polycentric (also see Laumann and Marsden 1979). The centralized network consists of a subset of actors that dictate decisions, while the more peripheral blocks exert little influence. The polarized network lacks central actors -- coalitions are clustered in two opposing camps, due to a dominant cleavage. In the bargaining model, core actors serve as mediators among and representatives for competing political constituencies. In the polycentric network, multiple cleavages separate coalitions, so that key actors are decentralized. Importantly, the mechanism giving rise to these distinct network

\footnotetext{
${ }^{1}$ Networks lacking central actors have also been observed in studies of gift giving (Malinoski 1922), marriage ties across subgroups (Bearman 1997), and sexual relationships (Bearman et al. 2004).
} 
structures is the degree of dissimilarity among the underlying constituencies of political actors (Laumann and Marsden 1979). The centrally administered network, for example, lacks cleavages among competing political interests, and in the polarized model there is only a single division among the parties. The bargaining and polycentric models both reflect multiple cleavages.

[Figure 1 about here]

Since a previous survey of Washington lawyers and lobbyists (Heinz et al. 1993),

found a network lacking central actors, we designed this research to provide a stringent test of that finding. On the assumption that lawyers' shared skills and knowledge would tend to draw them together, creating a set of core actors, we chose to focus on lawyers involved in a set of issues on which lawyers are especially active and in which their professional knowledge and skills are highly relevant. Thus, the question is: Will we find some lawyers acting as mediators or brokers, occupying the center of the network and serving to bridge left and right, or does the network have a hollow core, lacking actors who provide links between contending partisans?

\section{Lawyers' Characteristics, Roles, Political Ties, and Influence}

Social and political factors influence network structures. Political cleavages, reflecting ideological differences or varying political constituencies, create both ties and structural holes. Ties spanning multiple political boundaries may be especially difficult to create and maintain. Homophily - the tendency of individuals to associate with others who are similar ("birds of a feather flock together") - often influences connections. But while gender, age, education, race and ethnicity are well-known determinants of contact, less is known about the effects of lawyers' professional roles. Some lawyers attempt to influence 
public policy in courts, of course, while others work in legislatures, government agencies, the media, and grassroots campaigns (Laumann et al. 1985). These different types of political work often reinforce one another, and lawyers may engage in several strategies simultaneously and collaborate with other types of actors - e.g., lobbyists, media relations personnel, and community organizers - to accomplish their goals.

Lawyers who engage in legislative work seek to forge compromises among varying constituencies in order to create a winning coalition, while those who focus primarily on litigation might be less likely to build bridges across issue areas or ideological divides (although they sometimes build litigation alliances within their issue areas). Litigators may more often interact with other litigators than with lawyers who engage primarily in lobbying, media work, or grassroots strategies, and lawyer-lobbyists may be more likely to interact with others who engage in legislative work.

The issue agendas of organizational clients influence the network roles of their lawyers. Advocates for umbrella groups, for example, are more likely to serve as brokers than are lawyers who serve single issue advocacy organizations, and representatives of broad economic interests may be more likely to bridge constituencies than are advocates for groups committed to symbolic crusades (Salisbury et al. 1987). Moreover, particular policy issues are associated with particular strategies. For example, because obscenity and pornography are subject to settled (if vague) legal precedents that do not invite high profile litigation, lawyers involved in those issues generally fight their battles in legislatures and the press rather than in the courts. Their patterns of interaction may reflect this. In contrast, we might expect litigators - especially appellate advocates - to be prominent in the networks of political actors involved in unsettled and highly contested constitutional issues, such as abortion, gun control, 
property rights, and the relationship between church and state. Thus, we hypothesize that political ties will be more likely between lawyers who share work roles.

Finally, there are likely to be relationships between positions in the network and the relative influence of the actors in those positions. Lawyers who serve large, well-funded, stable organizations are more likely to hold pivotal positions in political networks than are lawyers who serve small, poor, and ephemeral groups (Paik et al. 2007). "Centrality” measures identify persons occupying core positions that are correlated with power, influence, status, and control of information (Freeman 1979; Friedkin 1991; Bonacich 1987; Paik et al. 2007). Because these centrality measures assess relationally-defined power, prestige, or influence, they are proxies for ability to lead. If some actors are particularly influential, as brokers or as leaders, it may be instructive to examine their attributes. We analyze the relationship between network centrality and the lawyers’ political contributions to federal election campaigns. Lawyers’ political contributions may reflect their status, political visibility, and/or level of commitment to the causes they serve.

\section{RESEARCH DESIGN}

The sample consists of forty-seven elite lawyers who worked for organizations involved in national policy issues during 2004 and 2005. To select this sample, we employed a “hypernetwork” approach (McPherson 1982), which involved first specifying a population of organizations involved in national policymaking and then identifying lawyers who served those organizations. We identified organizations that were active on matters classified as “legal affairs” issues by the Congressional Quarterly Almanac in 2004 and 2005. ${ }^{2}$ The

\footnotetext{
${ }^{2}$ In the study of political networks, it is crucial to define system boundaries (Laumann, Marsden \& Prensky 1989). We used newspaper accounts of a set of "issue events" to identify the active organizations (Knoke 1994). 
particular events (listed in Appendix Table A.1) concerned abortion, gay rights, asbestos compensation, class action lawsuits, DNA testing/victims' rights, flag desecration, identity theft, medical malpractice liability, guns, bankruptcy, judicial nominations, federal court jurisdiction, eminent domain, and the Terri Schiavo case. More than 2,000 interest groups appeared in news stories about these events in twenty newspapers and magazines (see Appendix Table A.2), but we focused on a subset of 119 organizations found in six or more news accounts. ${ }^{3}$ Those organizations, listed in Appendix Table A.3, include businesses, trade associations, membership organizations, religious groups, think tanks, and many of the bestknown liberal, conservative, and libertarian policy organizations.

We found that 1,149 lawyers served the 119 organizations in litigation or legislative testimony on the fourteen issues, or as registered lobbyists, or as members of the organizations' boards of directors. To select the lawyers who were most likely to be key players in public policy networks, we identified 98 lawyers who served more than one of the 119 organizations or who played multiple roles within an organization (e.g., as advocate and officer, or as board member and lobbyist). We then searched for the names of those 98 lawyers in four on-line sources: the Lexis/Nexis “major newspapers” database, $C Q$ Congressional Testimony, Roll Call, and National Journal. Forty-seven of the 98 lawyers were mentioned 100 or more times in those sources from 2000 through 2008. For each of these 47 lawyers, we gathered biographical information, data on campaign contributions to presidential races and the major parties from 2000 through 2008, and organizational ties (including employment, board memberships, and volunteer activities) during the same period,

3 Some of the nonprofit organizations listed "related" organizations on their IRS Form 990s. We included data about those organizations in our analysis. 
and we coded party affiliation based on the lawyers' patterns of contributions. We then constructed an affiliation matrix consisting of lawyers and their ties to organizations. ${ }^{4}$

\section{FINDINGS}

\section{Sample Characteristics}

The lawyers examined here are leaders of the organizations they serve and prominent advocates in the arenas that shape public policy, including courts, Congress, administrative and regulatory agencies, and the media. Collectively, they have held a variety of important positions in politics and government. Two were presidential candidates, one was Attorney General, two were governors, four were Congressmen, four were presidents of the American Bar Association, one was a state supreme court justice, one was counsel to the president, one was a cabinet secretary, five held White House staff positions, and two were U.S. attorneys. Many of them founded influential organizations. Some are accomplished appellate advocates, while others are among the most effective lobbyists in Washington. Brief biographies of the 47 lawyers are included in Appendix Table A4.

Table 1 presents descriptive statistics for the 47 lawyers. Perhaps reflecting the elite character of this set of lawyers, 83\% were men and 66\% were based in Washington, DC. Forty percent were known primarily as litigators or legislative advocates, while 60\% played broader roles in the organizations and causes they served, as organizational leaders. Roughly half were Democrats (49\%) and 43\% were Republicans; the remaining lawyers were not clearly identified with either major party. Nearly two-thirds of the lawyers were educated in top law schools: 28\% have law degrees from “elite” law schools, defined as the top 6 schools

\footnotetext{
${ }^{4}$ We converted the affiliation matrix (A) into a $47 \times 47$ matrix, $\mathbf{N}$, by multiplying $\mathbf{A}$ by its transpose $\left(\mathbf{N}=\mathbf{A}^{*} \mathbf{A}^{\prime}\right)$. Cell values in the $\mathbf{N}$ matrix indicate the number of shared ties to organizations for each pair of lawyers.
} 
in the 2000 U.S. News \& World Report rankings, and 34\% from schools ranked 7 through 20. In general, the 47 lawyers are well-connected and active in political campaigns. Their mean number of organizational ties and amount of political contributions were 7.3 and $\$ 13,012$, respectively. The latter figure reflects the exceptionally large contributions of C. Boyden Gray during this period; he alone gave $\$ 428,000$. The median contribution level was $\$ 1,300$.

[Table 1 about here]

\section{The Network Structure}

Figure 2 presents an analysis of ties among the 47 lawyers in the sample. ${ }^{5}$ The ties used here are joint affiliations with organizations. This is a "two-mode" analysis, meaning that we show both the individual lawyers and the organizations that connect pairs of lawyers. ${ }^{6}$ The data concerning ties are drawn from records of litigation and lobbying on the set of "legal affairs” issues, boards of directors lists, and lawyers' biographies. ${ }^{7}$

[Figure 2 about here]

In the figure, liberals and the organizations that pursue their causes usually appear on the left side of the space, while conservatives are on the right. At the upper right is the conservative establishment: the Heritage Foundation, Federalist Society, American Enterprise Institute, RAND Corporation, U.S. Chamber of Commerce, a former U.S. Attorney General (Meese), two former Congressmen (Porter and McIntosh), and two former governors (Keating and Engler). Just to the right of the middle are two very prominent Republicans -- Donald

\footnotetext{
${ }^{5}$ One lawyer, Keane, does not appear in the figure because he does not share an organizational affiliation with any of the other 46 lawyers.

${ }^{6}$ The analysis uses a "spring-embedding" algorithm. The lawyers and organizations, represented by points, are pulled together or apart by their varying ties to others. In the algorithm, these competing forces correspond to tension exerted by springs, and the springs pull against a constant force, pushing the actors apart. The resulting location of each point in the solution is a product of these several forces, operating simultaneously. ${ }^{7}$ Not all organizations that are included here appear in the news stories about the issue-events. Although many of them do appear there, this set of organizations is broader.
} 
Hodel, Secretary of the Interior in the Reagan administration and a former president of both the Christian Coalition and Focus on the Family, and C. Boyden Gray, counsel to the President in the first Bush administration and Ambassador to the European Union in the second. The positions of these two lawyers suggest that they could serve as mediators between differing elements of the Republican coalition, especially between business interests, in the middle right, and social conservatives, on the lower right.

Connections, indicated by lines linking organizations to lawyers, are especially dense just to the right of the center, where we find the Federalist Society, American Enterprise Institute, U.S. Chamber of Commerce, Bretton Woods Committee, Council for National Policy, ${ }^{8}$ the Bush and McCain presidential campaigns, Citizens for a Sound Economy, and the Brookings Institution (see 2, 3, and 4). This indicates that organizations and lawyers representing business interests, such Gray and Engler (President and CEO of the National Association of Manufacturers), are especially well-integrated. A smaller area with dense connections is below the center and a bit to the left (see 5 and 6). This area includes Thurgood Marshall, Jr., and some former presidents of the American Bar Association (Grey, Greco, and Curtin), as well as the ABA's chief lobbyist, Robert D. Evans. Note the presence here of Democratic election campaign organizations - - the Obama and Hillary Clinton presidential campaigns and the Democratic Senatorial Campaign Committee. The ABA appears to connect business interests to these liberal groups.

\footnotetext{
8 The Council for National Policy was founded in 1981 by Tim LaHaye, then head of the Moral Majority. It has been described as "a little-known club of a few hundred of the most powerful conservatives in the country [who, since 1981] have met behind closed doors at undisclosed locations for a confidential conference ... to strategize about how to turn the country to the right” (Kirkpatrick 2004).
} 
At the left of the space are organizations and lawyers devoted to particular liberal causes - - Planned Parenthood, People for the American Way, NAACP, Consumers Union, Leadership Conference for Civil Rights, Alliance for Justice, Brady Campaign to Prevent Gun Violence, and Third Way (formerly, Americans for Gun Safety). All but one of the eight women in the sample and all of the four African-American lawyers appear on the left side. The ties in this broad region are generally more sparse than they are on the right. This suggests that the liberals are less well-integrated, less densely-connected than are conservatives, especially business interests. We test this proposition more formally in the next section of the paper.

Libertarians and their advocates - Bob Barr (2008 Libertarian presidential candidate), Robert Levy (Cato Institute senior fellow), and Dana Berliner (Institute for Justice senior attorney) -- appear at the top center. In structural as well as ideological terms, these lawyers stand between liberals and conservatives.

There is an open area in the center of the space. The Hogan and Hartson law firm (H \& $\mathrm{H}$ ) is within this hole in the doughnut because Barnes (a Democrat) and Porter (a Republican) were both partners in that firm. (They are also both former Congressmen.) If we focus only on the lawyers, we see that those closest to the center are Porter, Hodel, Gray, Archer, Henderson (President of the Leadership Conference on Civil Rights), and Levy, arranged in a rough circle. Of these six, three held high office in the federal government and a fourth, Archer, was mayor of Detroit and president of the ABA. Meese, Barr, and Conrad are also near the center, and two of those three are also former federal officials. The organizations that provide the most links - - the ABA and the Federalist Society - - are located on the rim of this inner circle. Both are lawyers' professional associations. The ABA, the older and larger of the two, 
lobbies on a diverse range of public policy issues. The Federalist Society, a newer organization that presents itself as a conservative/libertarian "counter-ABA” (Teles 2008, 167), does not itself take formal policy positions. However, its fifteen nationwide practice groups facilitate members' involvement in public policy controversies ranging from securities and antitrust to religious liberties (Southworth 2008).

The litigators in this figure are active on policy issues in which constitutional case law is unsettled: abortion (Brown, Weber, Roger Evans), gun regulation (Henigan), property rights (Berliner), and church-state issues (Bull, Baylor, Mincberg). These lawyers are scattered on the periphery of the structure, indicating that they are not well-integrated in the network.

Figure 3 shows the lawyers' party affiliations. All of the Republicans are on the right side of the space, and all but one of the Democrats are on the left side. The exception, Jeffrey Peck, appears on the right due to his lobbying on behalf of the U.S. Chamber of Commerce. Peck's web page explains the seeming anomaly; it cites press coverage identifying him as one of the "leading Democratic lobbyists" and as the consultant "Wall Street turns to ... for representation in the Democratic-controlled Congress.”

[Figure 3 about here]

\section{Determinants of network ties and political contributions}

Table 2 presents structural blockmodels examining whether characteristics of the lawyers are associated with shared organizational ties. The models partition the matrix of co-affiliations based on lawyers' attributes (e.g., gender, party affiliation, etc.). The observed densities of ties within and across these categories are then compared to a distribution of densities generated by randomly permuting the rows and the columns of the matrix of lawyers. Thus, this blockmodeling approach tests whether the observed densities of ties in the blocks are 
significantly different from a distribution based on random interaction (Wasserman and Faust 1994; Hanneman and Riddle 2005).

In Model 1, we tested the hypothesis that shared ties within gender were more common than would be the case if the ties were randomly distributed. This model shows no significant parameters. Models 4 and 5 are also nonsignificant, suggesting that lawyers who share geographic region or law school background are not more likely to be tied than one would expect if interactions were random. Model 2, however, shows that shared party affiliation is associated with an increased probability of ties. Party affiliation explains $8 \%$ of the variance in pairwise ties. Specifically, the probability of ties across parties is .09, and this estimate is nonsignificant, indicating that cross-party ties are no different from random interactions. In contrast, both Republicans and Democrats are likely to be tied to lawyers who share their party affiliation. The probability of shared ties among Republicans is 27 percentage points greater than the probability of ties across party. ${ }^{9}$ For Democrats, the increased probability is 11 percentage points greater than cross-party ties. Finally, Model 4 shows the presence of homophily based on lawyers’ roles. Overall, shared roles explain 3\% of the variance in pairwise ties, but the only significant coefficient is for lawyers who are not primarily litigators or lobbyists. Lawyers who play broader roles are 14 percentage points more likely to be tied to one another than to lawyers in the other categories.

\section{[Table 2 about here]}

Taken together, the results of the structural blockmodels suggest that party affiliation and lawyers' roles are important determinants of the network structure. We also found that

\footnotetext{
9 While the significance test is based on the extent of difference from a random distribution, the comparison here is
} among observed patterns of the groups or categories. 
homophily biases are greater for Republicans than Democrats. This is evident in Figure 2, which shows substantially more clustering on the right side of the figure than on the left. The salience of ideological differences highlights the fact that the observed structure is an oppositional network.

Table 3 presents regressions of shared ties to other lawyers, or degree centrality, and of campaign contributions (logged), using the same variables. Because of our small sample size, we estimated stepwise regressions where only significant covariates were retained. ${ }^{10}$ The first model is a regression of the number of shared ties to other lawyers on party affiliation and lawyers' roles. This regression shows that lawyers who are Democrats have three fewer connections than Republicans ( $\mathrm{p}<.05$ ), controlling for the lawyers' roles, which is consistent with our previous findings. In addition, lawyers who play broader organizational roles tend to have almost six more connections than litigators. Lobbyists have approximately four more connections than litigators, but this finding was not statistically significant $(\mathrm{p}<.10)$.

\section{[Table 3 about here]}

In the model of political contributions, once we introduce degree centrality into the model none of the other covariates are significant. However, dummy variables for other party, lawyers' roles, and attending regional law schools were significant in bivariate regressions (results available upon request). This suggests that those three variables are associated with the level of political contributions, directly or indirectly, but that those associations are overwhelmed by the effect of network centrality, which is substantial. Each additional network tie is associated with

10 Network data are not independently drawn, so standard inferential statistics will not produce correct standard errors. Instead, we employ a bootstrapping regression approach that compares obtained parameter estimates against a distribution of parameter estimates generated through random permutations. The models presented in Table 3 are the final models for centrality and political donations. 
a 30\% increase in political contributions. It is possible that players who occupy central positions in the network may feel greater obligations or pressure to contribute to election campaigns, or their level of commitment to the causes they advocate may be greater. Alternatively, the relationship between centrality and the level of contributions may be attributable to a third variable such as status, prominence, or visibility.

\section{DISCUSSION}

Essentially, the network structure is a variant of Knoke’s "polarized” model, where a substantial cleavage divides political actors into two factions. Certainly, we find an oppositional network in which conflicting interest groups are located in separate areas of the space. It is sharply divided by party. The structure, however, is not simply two opposing camps with open territory between their lines. Rather, we see a network that resembles a rough circle, with a hole at its center. This occurs because political blocs have edges or boundaries where there is a greater proximity to other interest groups - - proximity both in terms of ideological position or programmatic goals and in terms of the likelihood of interaction. Interest group coalitions have centers and peripheries, and actors closer to the center or core of a coalition are likely to be purer in their views, stronger in their ideological commitments, and more supportive of the coalition's goals than are those at the margins (see, generally, Hogg 1987; Miller and Komorita 1986;

Levine and Moreland 1990).

Thus, if we think of a stylized network structure with competing interest coalitions formed into two lines, opposing phalanxes, the actors at the ends of each of those lines are less fully integrated into the respective coalitions and thus more susceptible to proposals offered across the lines. This will tend to bend the lines toward each other, perhaps in some cases 
forming a circle. In our case, left and right are brought together by mediating institutions such as the ABA and the ACLU.

In Figure 2, if we begin at the lower right and then move around the circle in a counterclockwise direction, we find that social and religious conservatives affiliated with the American Center for Law and Justice and the Alliance Defense Fund are connected to business interests through organizations like the Bush and McCain presidential campaigns and through lawyers like Sekulow. ${ }^{11}$ The ties of Hodel and Gray bridge business and religious conservative constituencies. Recall that Hodel held cabinet posts in the Reagan Administration and serves on various corporate boards, while also maintaining ties to Christian conservative groups. Gray, the epitome of the Washington insider and the Republican establishment, also organized the Committee for Justice, a business group that worked with social conservatives to secure confirmation of President Bush’s judicial nominees, including Chief Justice Roberts and Justice Alito. The Federalist Society, Heritage Foundation, and American Enterprise Institute, and lawyers such as Meese and Barr, tie business conservatives to libertarians such as Levy, of the Cato Institute, and Berliner, of the Institute for Justice. Libertarians are, in turn, a bridge (albeit a rather narrow one) to the left side of the space through the ACLU, with whom they share a commitment to First Amendment issues, including freedom of speech and freedom of association. The ACLU provides ties, direct and indirect, to organizations concerned with church and state issues, such as People for the American Way, and with civil rights, such as the NAACP and the Leadership Conference on Civil Rights. A branch of the network at the far left of the

\footnotetext{
${ }^{11}$ As chief counsel for the American Center for Law and Justice, Sekulow has handled most of the religious right's most important Supreme Court cases, but he also served with Gray and Meese on a team of lawyers advising President George W. Bush on judicial strategy. This team of lawyers, which also included Leonard Leo, executive vice president of the Federalist Society, dubbed themselves "the four horsemen" (Edsall \& Milbank 2005).
} 
space includes lawyers and organizations advocating consumer rights. The civil rights groups are also tied to gun control groups and the Kerry and Obama presidential campaigns. Continuing counterclockwise, and reaching the bottom of the space, there are ties to the Gore and Hillary Clinton campaigns and to former presidents of the ABA. The ABA and its lawyers, in turn, are linked to businesses, which brings us back to the point at which we began this paragraph. Victor Schwartz represents one bridge between conservatives and the leadership of the ABA. He is a founder of the American Tort Reform Association and advocates restrictions on tort liability, but he also has served as chair of the ABA's Legislative Subcommittee of the Product Liability Committee. ${ }^{12}$ Similarly, Robin Conrad, executive vice-president of the National Chamber Litigation Center, has directed litigation for the U.S. Chamber of Commerce on federal preemption, punitive damages, and class actions, and she also has been active in the ABA. Instead of displaying a simple, unidimensional cleavage, the structure is a multifaceted network in which distinct interest group constituencies overlap with others in agenda or ideology, so that one coalition shades into another through institutional ties. Work roles and geographic locations shape these ties, making some sorts of connection more likely than others. As we saw in Figure 2 and Table 3, lawyers who are primarily litigators are less well-integrated than lawyers who play broader roles.

The only tie that bridges the open center of the space is that between Barnes on the left and Porter on the right, through their shared affiliation with the Hogan and Hartson law firm. This tie, and those through the Georgetown Law School and the U.S. Supreme Court Historical

12 In our analysis of the lawyers' individual campaign contributions, we found that Schwartz has primarily supported Republicans but has also given money to Democrats. 
Society, may not advance shared political goals, but they provide an institutional framework or setting in which contacts are made and operational connections can be formed.

The other striking characteristic of this network is that ties among conservatives, especially business conservatives, are notably more dense than those among liberals. It appears that liberals have not created umbrella groups that effectively integrate lawyers associated with varying liberal causes in a manner analogous to the function performed for the right by the Federalist Society, the Heritage Foundation, and the American Enterprise Institute. Conservative patrons and organizational entrepreneurs have sought to create opportunities for interaction among lawyers with diverse ideological commitments (Southworth 2008). This strategy was based on the belief that common professional perspectives and joint occupational interests would enable lawyers to promote comity among the sometimes conflicting constituencies of the Republican coalition and encourage them to cooperate in public policymaking. Liberal coalitions such as the Alliance for Justice and the Leadership Conference on Civil Rights claim to speak for diverse groups on the political left, ${ }^{13}$ and they may well help liberal groups forge common positions. But their integrative role is not discernable in the organizational affiliations of this sample of individual lawyers. The American Constitution Society is an effort to create a liberal equivalent of the Federalist Society, ${ }^{14}$ but the ACS does not appear in our data.

Established professional institutions, such as the Federalist Society and American Bar Association, which appear to play important roles in organizing this network, command their

\footnotetext{
13 The Leadership Conference's members include many of the 119 organizations from which our sample of lawyers was drawn, such as the ACLU, NAACP, AARP, National Consumer Law Center, Lambda, NOW, National Women's Law Center, Planned Parenthood, Feminist Majority, NOW, AFL-CIO, and People for the American Way. Many members of the Alliance for Justice were also on our list of organizations - e.g., Lambda, NOW, National Abortion Federation, National Women's Law Center, Planned Parenthood, and the Sierra Club.

${ }^{14}$ For analyses of the Federalist Society's role in integrating the conservative coalition, see Paik et al. (2007), Southworth (2008).
} 
own loyalties. These organizations provide opportunities for lawyers to further their careers by increasing their visibility and acquiring contacts with other lawyers who may be in a position to refer clients or provide other professional advantages. Such organizations, as a consequence, draw lawyers together around purposes distinct from the objectives of the clients they serve. Some lawyers become institutional politicians, seeking to advance their status within the organizational hierarchy.

Our research design, of course, identifies only some of the relevant links among these lawyers. We did not interview them, and we know little about their acquaintances. They may make useful connections with other lawyers at churches and synagogues, fitness classes and book groups, the opera or their children's soccer games. Such ties might serve as a basis for cooperation in public policymaking through informal means that are not seen in the forms of joint participation examined here. It is also possible that these lawyers participate in joint litigation and legislative activities on matters not included in the "legal affairs" issues that are the focus of this study. Nonetheless, this research suggests that liberals do not enjoy the dense web of organizational ties that previous research documented among prominent lawyers of the right (Paik et al. 2007; Heinz et al.2003). If lawyer networks provide channels for cooperation and serve to lessen conflict and facilitate constructive bargaining among disparate constituencies, the political right may hold a distinct advantage over its rivals. 


\section{REFERENCES}

Bearman, Peter. 1997. Generalized Exchange. American Journal of Sociology 102:1383-415.

Bearman, Peter S., James Moody, and Katherine Stovel. 2004. Chains of Affection: The Structure of Adolescent Romantic and Sexual Networks. American Journal of Sociology 110:33-91.

Bonacich, Phillip. 1987. Power and Centrality: A Family of Measures. American Journal of Sociology 92:1170-1182.

Domhoff, G. William. 1983. Who Rules America Now? A View from the '80s. Englewood Cliffs, NJ: Prentice Hall.

Edsall, Thomas B. and Dana Milbank. 2005. The Right’s Moment, Years in the Making. Washington Post, July 3, A1.

Epp, Charles R. 1998. The Rights Revolution: Lawyers, Activists, and Supreme Courts in Comparative Perspective. Chicago: University of Chicago Press.

Freeman, Linton. 1979. Centrality in Social Networks: Conceptual Clarifications. Social Networks 1:125-39.

Friedkin, Noah E. 1991. Theoretical Foundations for Centrality Measures. American Journal of Sociology 96:1478-504.

Galanter, Marc. 1974. Why the 'Haves' Come Out Ahead: Speculations on the Limits of Legal Change. Law and Society Review 9:95-160.

Grossman, Joel B., Herbert M. Kritzer, and Stewart Macaulay. 1999. Do the 'Haves' Still Come Out Ahead? Law and Society Review 33:803-10. 
Hanneman, Robert A., and Mark Riddle. 2005. Introduction to Social Network Methods. Riverside, CA: University of California, Riverside (published in digital form at http://faculty.ucr.edu/ hanneman/).

Heinz, John P., Edward O. Laumann, Robert L. Nelson, and Robert H. Salisbury. 1993. The Hollow Core: Private Interests in National Policymaking. Cambridge, MA: Harvard University Press.

Heinz, John P., and Edward O. Laumann. 1982. Chicago Lawyers: The Social Structure of the Bar. New York: Russell Sage Foundation.

Heinz, John P., Robert L. Nelson, Rebecca L. Sandefur, and Edward O. Laumann. 2005. Urban Lawyers: The New Social Structure of the Bar. Chicago: University of Chicago Press.

Heinz, John P., and Peter Manikas. 1992. Networks Among Elites in a Local Criminal Justice System. Law and Society Review 26:831-61.

Hogg, Michael A. 1987. Social Identity and Group Cohesiveness. In Rediscovering the Social Group, ed. John C. Turner, with Michael A. Hogg, Penelope J. Oakes, Stephen D. Reicher, and Margaret S. Metherell, 89-116. New York: Basil Blackwell.

Kirkpatrick, David D. 2004. Club of the Most Powerful Gathers in Strictest Privacy. New York Times, August 28, A10.

Knoke, David. 1990. Political Networks: The Structural Perspective. New York: Cambridge University Press.

Knoke, David. 1994. Networks of Elite Structure and Decision Making. In Advances in Social Network Analysis: Research in the Social and Behavioral Sciences, ed. Stanley Wasserman and Joseph Galaskiewicz. Thousand Oaks, CA: Sage. 
Laumann, Edward O., and John P. Heinz, with Robert L. Nelson and Robert H. Salisbury. 1985. Washington Lawyers: The Structure of Washington Representation. Stanford Law Review 37:456.

Laumann, Edward O., and Peter V. Marsden. 1979. The Analysis of Oppositional Structures in Political Elites: Identifying Collective Actors. American Sociological Review 44:713732.

Laumann, Edward O., Peter V. Marsden and David Prensky. 1989. The Boundary Specification Problem in Network Analysis. In Research Methods in Social Network Analysis, ed. Linton C. Freeman and Douglas R. White. Fairfax, VA: George Mason University Press. Levine, John M. and Richard L. Moreland. 1990. Progress in Small Group Research. Annual Review of Psychology 41:585-634, at 603-11.

Malinoski, Bronislaw. 1922. Argonauts of the Western Pacific. Prospect Heights: Waveland. McPherson, J. Miller. 1982. Hypernetwork Sampling: Duality and Differentiation among Voluntary Organizations. Social Networks 3:225-49.

Miller, Charles E. and Samuel S. Komorita. 1986. Coalition Formation in Organizations. In Research on Negotiation in Organizations, ed. Roy J. Lewicki, Blair H. Sheppard, and Max H. Bazerman, 117-37. Greenwich, CT: JAI Press.

Mills, C. Wright. 1956. The Power Elite. New York: Oxford University Press.

Moore, Gwen. 1979. The Structure of a National Elite Network. American Sociological Review 44:673-92.

Paik, Anthony, Ann Southworth, and John P. Heinz. 2007. Lawyers of the Right: Networks and Organization. Law and Social Inquiry 32:883-917. 
Salisbury, Robert, John P. Heinz, Edward O. Laumann and Robert L. Nelson. 1987. Who Works with Whom? Interest Group Alliances and Opposition. American Political Science Review 81:1217-34.

Southworth, Ann. 2000. The Rights Revolution and Support Structures for Rights Advocacy. Law and Society Review 34:1203-20.

Southworth, Ann. 2008. Lawyers of the Right: Professionalizing the Conservative Coalition. Chicago: University of Chicago Press.

Southworth, Ann, Anthony Paik and John P. Heinz. 2010. Lawyers in National Policymaking. In Law and the Possibility of Justice, ed. Scott Cummings. Cambridge: Cambridge University Press, forthcoming.

Teles, Steven. 2008. The Rise of the Conservative Legal Movement. Princeton: Princeton University Press.

Useem, Michael. 1983. The Inner Circle: Large Corporations and Business Politics in the U.S., and the U.K. New York: Oxford University Press.

Wasserman, Stanley, and Katherine Faust. 1994. Social Network Analysis: Methods and Applications. Cambridge: Cambridge University Press.

\section{CASES CITED}

District of Columbia v. Heller, 554 U.S. (2008).

Kelo v. New London, 545 U.S. 469 (2005). 


\section{$\underline{\text { Appendix A }}$}

\section{Table A1: The Issue Events}

Fetal Protection (2004): Congress passed a bill (HR 1997—PL 108-21), which President Bush signed, giving federal legal status to a fetus. The legislation made it a separate offense to harm a fetus during the commission of a federal crime against a pregnant woman.

Gay Rights (2004): A proposed constitutional amendment to ban gay marriage failed in the House and Senate (S J Res 40, H J Res 106). Republicans hoped to prevent judges from invalidating the 1996 Defense of Marriage Act, which defined marriage as "a legal union between one man and one woman.”

Asbestos Compensation (2004): Republican Senators failed to pass legislation (S 2290) to create a no-fault compensation fund for victims of asbestos exposure.

Class Action Lawsuits (2004): Failed Republican legislation (S 2062) would have limited plaintiffs' opportunities to file class action lawsuits in state courts.

DNA Testing/Victims Rights (2004): Legislation was signed into law (HR 5107—PL 108-405) making it easier for inmates to gain access to post-conviction DNA tests while also allowing retrials for cases in which test results indicated an inmate might not be guilty.

Flag Desecration (2004): A proposed constitutional amendment to criminalize physical desecration of the American flag failed to move beyond the Senate Judiciary Committee (S J Res 4).

Identity Theft (2004): On July 15, President Bush signed into law a bill cleared by Congress (HR 1731—PL 108-275) establishing stronger criminal penalties for identity theft.

Medical Malpractice (2004): Republicans attempted but failed to cap non-economic damage awards in medical malpractice suits (S 2061).

Guns (2004): Due to a number of Democratic amendments, such as one renewing the 1994 ban on semi-automatic assault weapons, Republican Senators failed to pass legislation (S 1805) aimed at limiting the firearm industry's liability for gun violence. The bill would have barred civil lawsuits against manufacturers, distributors, and importers of firearms and ammunition.

Bankruptcy Overhaul (2004): Despite extensive bipartisan support for legislation aimed at making it more difficult for individuals to erase their debts by filing for bankruptcy protection, Congress was unable clear the bill (HR 975, S1920). Nonetheless, Congress did pass legislation allowing family farmers to restructure their debts without losing their land (S 2864—PL 108369). 
Judicial Nominations (2004): Although Democratic Senators blocked 10 of Bush's appellate court nominees through procedural votes, Bush nonetheless filled 203 lifetime seats on federal district and appellate courts. Moreover, Republicans pushed for a Senate rules change- the "nuclear option"-requiring only a 51-vote majority to break filibusters of judicial nominees.

Federal Court jurisdiction (2004): In an attempt to limit federal judges' jurisdiction over certain types of cases while also redrawing appellate court maps, the House passed three bills: HR 3313 barred federal courts from hearing cases challenging a provision of the Defense of Marriage Act; HR 2028 denied federal courts jurisdiction over challenges to the wording of the Pledge of Allegiance; and, S 878 added provisions to divide the $9^{\text {th }}$ Circuit into three separate appeals courts.

Judicial Nominations (2005): After Justice Rehnquist’s death, Bush nominated John Roberts to succeed Justice Sandra Day O'Connor as Chief Justice, and the Senate confirmed. The Senate also confirmed the nomination of Samuel Alito to the U.S. Supreme Court and five of seven previously filibustered lower federal court nominees.

Asbestos Compensation (2005): On May 26, the Senate Judiciary Committee approved a bill (S 852 — S Rept 109 — 97) creating a $\$ 140$ billion trust fund to compensate people sickened by asbestos exposure.

Medical Malpractice (2005): In an effort to cap non-economic damage awards in medical malpractice cases at $\$ 250,000$ and to limit punitive damages to two times the economic damages or $\$ 250,000$, Republicans passed a bill in the House (HR 5), but failed in the Senate.

Class Action Lawsuits (2005): On Feb.18, President Bush signed a measure giving federal courts jurisdiction over class action lawsuits when the total amount in dispute exceeded \$5 million and the defendant and a large portion of the plaintiffs lived in different states (S 5-PL 109-2).

Eminent Domain (2005): The House Judiciary Committee decisively approved a measure (HR 4128 - H Rept 109-262) limiting the effects of a controversial Supreme Court ruling (Kelo V. New London) on eminent domain. The bill sought to prohibit states and localities receiving federal development funds from using eminent domain to seize private property for economic development.

Guns (2005): Legislation limiting the legal liability of firearms makes and dealers was cleared and signed into law. Democrats attached several amendments, including a requirement that child safety locks be sold with all handguns.

Flag Desecration (2005): The House passed a proposed constitutional amendment (HJ Res 10-H Rpt 109-131) to criminalize physical desecration of the American flag, but the Senate did not clear the bill. 
Abortion (2005): The House passed a bill (HR 748) to expand the reach of state laws requiring parental consent or notification when a minor seeks an abortion. The measure required doctors to notify parents in person or by mail of an out-of-state minor's request for an abortion, and it gave guardians the right to sue noncompliant doctors.

Terri Schiavo Case (2005): The House and Senate passed a bill to allow the parents of Terri Schiavo to go to federal court and have their daughter's feeding tube restored. However, federal courts rebuffed Schiavo's parents' attempt to intervene.

\title{
Table A2: List of Media for Issue Event Searches
}

\author{
Wall Street Journal \\ New York Times \\ Washington Post \\ Los Angeles Times \\ Chicago Tribune \\ Dallas Morning News \\ Atlanta Journal \& Constitution \\ Time \\ Newsweek \\ U.S. News \& World Report \\ National Journal \\ Washington Monthly \\ Roll Call \\ Washington Times \\ National Review \\ The Nation \\ Weekly Standard \\ American Spectator \\ The New Republic \\ The American Prospect
}

\section{Table A3: Organizations}

\section{AFL-CIO}

Allan Guttmacher Institute

Alliance Defense Fund

Alliance for Justice

Alliance for Marriage

American Association of Retired Persons

American Bankers Association

American Bankruptcy Institute

American Bar Association 
American Center for Law and Justice

American Civil Liberties Union

American Conservative Union

American Enterprise Institute

American Family Association

American Insurance Association

American Legion

American Medical Association

American Tort Reform Association

American Values

Third Way

Americans for Tax Reform

Americans United for Separation of Church and State

America's Health Insurance Plans

American Association for Justice

Arlington Group

Bank of America

Brady Campaign to Prevent Gun Violence

Brookings Institution

Cato Institute

Center for a Just Society

Center for Responsive Politics

ChoicePoint, Inc.

Christian Coalition of America

Christian Defense Coalition

Citigroup

Citizens Flag Alliance

Club for Growth

Coalition for Asbestos Reform

Committee for Justice

Concerned Women for America

Consumer Federation of America

Democratic Leadership Council

Democratic National Committee

Dupont Co.

Eagle Forum

Earthjustice

Environmental Working Group

Equitas Ltd.

Ethics and Religious Liberty Commission of the Southern Baptist

Convention 
Exxon Mobil Corp

Family Foundation

Family Research Council, Inc.

Federal Mogul Co.

Federalist Society

Feminist Majority Foundation

Feminists for Life

Fidelis

Focus on the Family

Ford Motor Co.

Foundation for Taxpayer and Consumer Rights

Foundation for the Defense of Democracies

Free Congress Foundation

Freedom Works

General Electric

Georgia Equality

Georgia Hospital Association PAC

Georgia-Pacific Corp

Georgia Right to Life

Georgia Watch

Gun Owners of America

Halliburton Co.

Heritage Foundation

Human Rights Campaign

Identity Theft Resource Center

Innocence Project

Institute for Justice

Judicial Confirmation Network

Kaiser Family Foundation

Lambda Legal Defense and Education Fund

Leadership Conference on Civil Rights

Log Cabin Republicans

MAG Mutual Insurance Co.

Manhattan Institute

Massachusetts Family Institute

Medical Mutual Liability Insurance Society of Maryland

Medical Society of the District of Columbia

Move On

NAACP

NARAL Pro Choice America

National Abortion Federation 
National Association of Consumer Bankruptcy Attorneys

National Association of Evangelicals

National Association of Manufacturers

National Consumer Law Center

National Gay and Lesbian Task Force

National Organization for Women

National Retail Federation

National Rifle Association

National Right to Life Committee

National Shooting Sports Foundation

National Women's Law Center

Operation Rescue

People for the American Way

Pew Research Center

Physician Insurers Association of America

Planned Parenthood Federation of America

Progress for America

Public Citizen

Rand Corp.

Sierra Club

Texas Medical Society

Traditional Values Coalition

Trial Lawyers Association of Metropolitan Wash DC

U.S. Chamber of Commerce

U.S. Conference of Catholic Bishops

U.S. Public Interest Research Group

USG Corp.

Veterans of Foreign Wars

W.R. Grace and Company 


\section{Table A4: Biographical Sketches}

Anderson, Stanton. Senior counsel, U.S. Chamber of Commerce. Heads legislative coalitions to address "Global Regulatory Divergence" and to protect the lawyer-client privilege. Chaired the Class Action Business Coalition, which won passage of the Class Action Reform Act of 2005. Counsel to the Reagan/Bush campaign in 1980, and served in White House and State Department in the Nixon administration. Board member, Global U.S.A., a government relations firm.

Archer, Dennis. Chair, Dickinson, Wright, Moon, Van Dusen \& Freeman; partner since 1991. President of the ABA, 2002-2003. Mayor of Detroit, 1994-2001. Justice, Michigan Supreme Court, 1986-90. Former president, National Bar Association. Life member, NAACP.

Aron, Nan. President and founder, Alliance for Justice. Created AFJ's Judicial Selection Project, which helped to defeat Robert Bork's nomination to the U.S. Supreme Court in 1987 and to organize Senate filibuster of some of President George W. Bush's judicial nominees. Runs advocacy training programs to promote student social justice activism. Author of Liberty and Justice for All: Public Interest Law in the 1980s and Beyond. Formerly worked for the National Prison Project of ACLU and for the EEOC.

Barnes, Michael. Partner, Covington \& Burling 2007. Previously partner in Hogan \& Hartson. President of the Brady Campaign to Prevent Gun Violence, 2000-2006. Maryland Congressman, 1979-1987. Has chaired numerous committees dealing with international issues and has represented the governments of Chile, Cyprus, Panama, and South Korea. Served as Chair of Center for National Policy and Co-Chair of the U.S. Committee for the United Nations Development Program. Member, Council on Foreign Relations.

Barr, Bob. President, Liberty Strategies, a consulting firm in Atlanta. Libertarian Party presidential candidate, 2008. Columnist, American Conservative Union, 2003-2008. Congressman from Georgia, 1995-2003. U.S. Attorney for the Northern District of Georgia, 1986-90. President of Southeastern Legal Foundation, 1990-91. Contributing editor, American Spectator. Board member, NRA, and IForce, a domestic and international security company.

Bauer, Gary. Founder and president, American Values, 2000-present. Founder and chairman of Campaign for Working Families, 1996-present. President of the Family Research Council from 1988 to 1999, but resigned to seek the Republican presidential nomination in 2000. Served as Deputy Assistant Director of Legal Policy (1981-82), Deputy Undersecretary of Education (1982-85), and Undersecretary, U.S. Dept of Education (1985-1987) in the Reagan administration. Has been active on judicial nominations, the proposed federal marriage protection act, and Israeli security.

Baylor, Gregory. Senior counsel, Alliance Defense Fund. Litigates on behalf of Christian causes, especially to protect the rights of Christians at public colleges and universities. Formerly director of the Christian Legal Society Center for Law and Religious Freedom, Springfield, VA. 
Bennett, Matt. Vice-President for government affairs (and co-founder) of Third Way. Communications Director for Clark for President campaign, 2004. Director of public affairs for Americans for Gun Safety, 2001-04. Deputy assistant to the President in the Clinton administration, responsible for liaison to governors.

Berliner, Dana. Senior attorney, Institute for Justice. Specializes in eminent domain and administrative law issues. Best known for role in representing the homeowners in Kelo v. New London.

Brown, Jennifer. Pro bono counsel at Morrison \& Foerster, New York. Formerly legal director of Legal Momentum (now called the NOW Legal Defense and Education Fund), after serving in the Civil Rights Bureau of the NY Attorney General.

Bull, Benjamin. Executive Vice-President and chief counsel of the Alliance Defense Fund. Formerly executive director of the European Center for Law and Justice, Strasbourg. Founding general counsel of the American Family Association Law Center, and general counsel of the Children's Legal Foundation. Lead attorney in more than 300 cases, many dealing with constitutional issues.

Cavendish, Elizabeth. Executive Director, Appleseed. Interim president (2004) and legal director (1998-2003), NARAL. Formerly, office of legal counsel, U.S. Dep't of Justice; assistant prof., U. of Illinois law school.

Chambers, Julius. Of counsel in Ferguson Stein Chambers, etc., Charlotte, NC. Formerly Director/Counsel of the NAACP Legal Defense Fund, and then chancellor of North Carolina Central University. Director of Center for Civil Rights at UNC law school.

Cicconi, James. Senior Executive V-P for external and legislative affairs, AT\&T. Partner, Akin Gump, 1991-98. Assistant to President Reagan, 1989-90, and deputy chief of staff to President George H.W. Bush. Director, El Paso Electric Co. Advisor to the Bush/Cheney transition. Trustee, Brookings Institution.

Claybrook, Joan. President of Public Citizen, 1982-2008; lobbied for highway and auto safety laws. Chaired the National Highway Traffic Safety Administration 1977-81. Formerly worked for PIRG, National Traffic Safety Bureau, SSA, and the U.S. Dep't of HEW. Board member, Consumers Union.

Conrad, Robin. Executive Vice President of the National Chamber Litigation Center of the U.S. Chamber of Commerce. Has directed Chamber's litigation on federal preemption, punitive damages, and class actions. Attorney/advisor to the EPA in the Reagan Administration. Member of ABA Committee on the Status and Future of Federal e-Rulemaking.

Curtin, John. Of counsel, Bingham McCutchen, Boston; partner there 1964-2005. ABA president, 1990-91. President, Boston Bar Association, 1979-81. Chaired Joint Bar Committee on Judicial Appointments. Formerly Vice President and a Director of Greater Boston Legal 
Services and Chair of Ad Hoc Committee for Access to Justice. Board of directors, Nat'l Consumer Law Center. Board, Nat'l Legal Aid and Defender Ass'n, 1990-95. Nat'l Ass'n Public Interest Law. President, Fellowships for Equal Justice, 1992-95.

Engler, John. President and CEO, National Association of Manufacturers, 2004-present. President of state and local governmental sector of Electronic Data Systems. Governor of Michigan, 1991-2003. Michigan State Representative, 1970-79; Michigan State Senator, 19791990. On boards of Delta Airlines, Universal Forest Products, and Committee for Justice.

Evans, Robert. Director, Washington office of the ABA. Recipient of Nat'l Legal Aid and Defender Ass’n Special Achievement Award, 1990. President, Project Northstar, 2004-06. Member, American Law Institute.

Evans, Roger. Senior director of public policy litigation and law, Planned Parenthood. Counsel in major reproductive rights cases since 1983. Formerly was managing attorney of MFY Legal Services in New York City.

George, Robert. Professor of jurisprudence, Princeton University. Director, James Madison Program in American Ideals and Institutions. Member, U.S. Commission on Civil Rights, 199398, and President's Council on Bioethics, 2002-2005. Recipient of the Paul Bator Award from the Federalist Society and the Silver Gavel Award from the ABA. On numerous boards, including Institute on Religion and Democracy, Faith and Reason Institute, Family Research Council, and Council on Foreign Relations.

Gould, James. Partner, Capitol Counsel. Specializes in tax and international trade. Formerly worked as counsel to Senate Finance Committee under Chairman Lloyd Bentsen. Represents energy, insurance, and financial services companies. Formerly a partner in Vinson \& Elkins and then Capitol Tax Partners, a tax policy lobbying firm.

Gray, C. Boyden. Special envoy to the European Union, 2008-09. U.S. Representative to European Union, 2006-07. Partner, Wilmer Cutler, Washington, 1976-81 and 1993-2005. Chairman, Citizens for a Sound Economy, 1993-2000. Counsel to the President, 1989-93. Director of the Bush-Cheney Transition Department of Justice Advisory Committee. Chairman of administrative law section of ABA, 2000-02. U.S. Marine Corps, 1964-70. On numerous boards, including FreedomWorks, Federalist Society (board of visitors), Committee for Justice, Atlantic Council, and Harvard University’s Committee on University Development.

Greco, Michael. Partner, K\&L Gates, Boston. President of the ABA, 2005-06. Former president, Massachusetts Bar Association, New England Bar Association, and New England Bar Foundation. Active on legal services for the poor, civic education, separation of powers, and nuclear arms control. Member of Commission on Federal Judicial Appointments, and vice-chair of the Board of Overseers of the Massachusetts Supreme Judicial Court. Member, American Law Institute. 
Greenberg, Sally. Executive director, National Consumers League and co-chair, Child Labor Coalition. Senior product safety counsel at Consumers Union, Washington, 1997-2007; lobbied on auto safety, food and drug safety, product liability. Worked on Toby Moffett's Congressional staff 1977-81, and for the Anti-Defamation League, 1985-1996. Board member, Alliance for Justice, HALT.

Greenberger, Marcia. Founder and co-President, National Women's Law Center. Active in legislative and litigation campaigns to expand women's rights, particularly in connection with education, employment, health, reproductive rights, and family economic security. Member of the Executive Committee of the Leadership Conference on Civil Rights and the American Bar Association's Commission on Diversity. American Law Institute member.

Grey, Robert. Partner in Hunton \& Williams. President of the ABA in 2004-05. Practice specializes in governmental relations and administrative law in state and federal agencies. Washington and Lee University Board of Trustees.

Henderson, Wade. President and CEO of the Leadership Conference on Civil Rights. Longtime lobbyist on civil rights issues. Formerly worked for ACLU and NAACP. Has lobbied for affirmative action, welfare, gun control, immigrant rights, etc.

Henigan, Dennis. Director of the Legal Action Project of the Brady Center to Prevent Gun Violence and legal director of the Brady Campaign to Prevent Gun Violence. Litigates cases against firearms dealers and manufacturers and lobbies for stronger gun control law. Formerly, partner at Foley \& Lardner.

Hodel, Donald Paul. Chairman of FreeEats.com/cc Advertising, which has conducted "push polls" for the Economic Freedom Fund. President of Focus on the Family, 2003-05. President of Christian Coalition, 1997-99. Secretary of the Interior, 1985-89, and Secretary of Energy, 198285. Member of the board, Focus on the Family, and board of visitors, the Federalist Society.

Jenkins, Timothy. Partner in Nossaman LLP. Specializes in federal elections and ethics law. Lobbies for financial services and pharmaceutical companies and industry associations. Active in organizing and administering/managing PACs. Former staff member, Senate committees on Government Affairs and Labor and Human Resources.

Keane, Lawrence. Senior vice president and general counsel, National Shooting Sports Foundation. Lobbies on behalf of the firearms industry.

Keating, Francis. President, American Council of Life Insurers, 2003-present. Governor of Oklahoma, 1995-2003. In the Reagan administration, he was an assistant secretary of the Treasury (1985-88), and then an associate attorney general (1988-89). In the Bush I administration, he was general counsel and acting deputy secretary of HUD. U.S. attorney for the Northern District of Oklahoma, 1981-84. Former chairman of the Interstate Oil and Gas Compact Commission and the Republican Governors Association. 
Levy, Robert. Senior fellow, Cato Institute. Founder and former CEO, CDA Investment Technologies. Board member, Institute for Justice, George Mason Law School, and member of the board of advisors, Federalist Society. Organizer and financier of litigation challenging D.C.'s gun-control statute, which the U.S. Supreme Court invalidated in District of Columbia $v$. Heller. Co-author of The Dirty Dozen: How Twelve Supreme Court Cases Radically Expanded Government and Eroded Freedom.

Lynn, Barry. Executive Director, Americans United for Separation of Church and State, 1992present. Legislative counsel of ACLU, 1984-1991; president of Draft Action, Inc., 1981-83. Ordained minister, United Church of Christ, since 1974. Author of Piety \& Politics: The RightWing Assault on Religious Freedom.

McIntosh, David. Partner in Mayer Brown, Washington. Represents telecommunications, energy, and healthcare companies. Former Congressman from Indiana, 1995-2001. Founder and board chairman, Federalist Society. Special assistant to the President for domestic affairs in the Reagan administration, and director of the President's Council on Competitiveness in the Bush I administration.

Marshall, Thurgood Jr. Partner in Bingham McCutcheon. Assistant to the President and cabinet secretary in the Clinton White House, 1997-2001, and director of legislative affairs for Vice President Gore. Previously counsel to three Senate committees, including Judiciary. Board member, Ford Foundation, U.S. Postal Service, and Corrections Corporation of America.

Meese, Edwin. Distinguished Fellow in Public Policy and Chair of the Center for Legal and Judicial Studies, Heritage Foundation. Distinguished Visiting Fellow, the Hoover Institution. U.S. Attorney General in the Reagan Administration, 1985-88 Serves on many boards, including the Council on National Policy, Claremont Institute, Criminal Justice Legal Foundation, American Civil Rights Union, Capital Research Center, Intercollegiate Studies Institute, and Federalist Society (board of visitors).

Mincberg, Elliot. Chief Counsel for Oversight and Investigations, House Judiciary Committee, since 2007. Previously vice president, general counsel, and legal director of People for the American Way, . Litigated religious liberty and First Amendment cases, including school prayer and vouchers. Formerly a partner in Hogan and Hartson.

Peck, Jeffrey. Partner, Peck, Madigan, Jones \& Stewart, 2001-present. Former managing director of government and regulatory affairs of Andersen Worldwide, 1993-2000. Has lobbied on Supreme Court nominations, flag burning, class action procedures, and financial services issues. Formerly majority staff director of the Senate Judiciary Committee (then chaired by Sen. Biden). Described by National Journal as one of the "leading Democratic lobbyists" and by The Hill as the consultant "Wall Street turns to . .. for representation in the Democratic-controlled Congress.”

Porter, John Edward. Partner, Hogan \& Hartson. Former Congressman from Illinois, 19802001. Lobbyist on health issues. Board of directors, Corporation for Public Broadcasting, RAND 
Corporation, American Heart Association, Population Resource Center, Trustee, Brookings Institution.

Reed, Stephen. Partner in Reed \& Brown, Pasadena. Specializes in commercial real estate, general business and corporate law, and non-profit organization. Board member, Focus on the Family and Family Research Council.

Rich, Michael. Executive vice president, RAND Corporation, since 1993. Formerly head of the RAND National Security Research Division and director of the National Defense Research Institute. Chair, Int'l Institute for Strategic Studies - U.S. Board member, Council for Aid to Education, Council on Foreign Relations, WISE \& Health Aging.

Saperstein, David. Director and Counsel, Religious Action Center of Reform Judaism. Has led several national religious coalitions on social justice issues. Elected first Chair of U.S. Commission on Int'l Religious Freedom, 1999, and appointed by President Obama to White House Council on Faith-Based and Neighborhood Partnerships. Board member, NAACP, People for the AmericanWay. Adjunct professor, Georgetown Law School. Author of Jewish Dimensions of Social Justice: Tough Moral Choices of Our Time.

Schwartz, Victor. Partner, Shook Hardy \& Bacon, Washington. Practice specializes in insurance defense. General counsel, American Tort Reform Association. Chair, Civil Justice Reform Committee of the American Legislative Exchange Council. Chairman, Dep't of Commerce Task Force on Product Liability and Accident Compensation, 1977-80. Co-author of casebook: Prosser, Wade \& Schwartz's, Cases and Materials on Torts $\left(10^{\text {th }}\right.$ ed. 2000). On board of visitors of the University of Cincinnati law school.

Sekulow, Jay. Chief Counsel, American Center for Law and Justice and the European Center for Law and Justice. Has argued numerous religious liberty cases before the Supreme Court Host of national call-in radio program, “Jay Sekulow Live!”, and a weekly television program, ACLJ This Week.. Adjunct professor, Regent University. Board of Trustees, Supreme Court Historical Society. Member of, and lawyer for, Jews for Jesus.

Weber, Walter. Senior litigation counsel for the American Center for Law and Justice. Formerly staff attorney with Catholic League for Religious and Civil Rights. 
Figure 1 (from Knoke 1990)

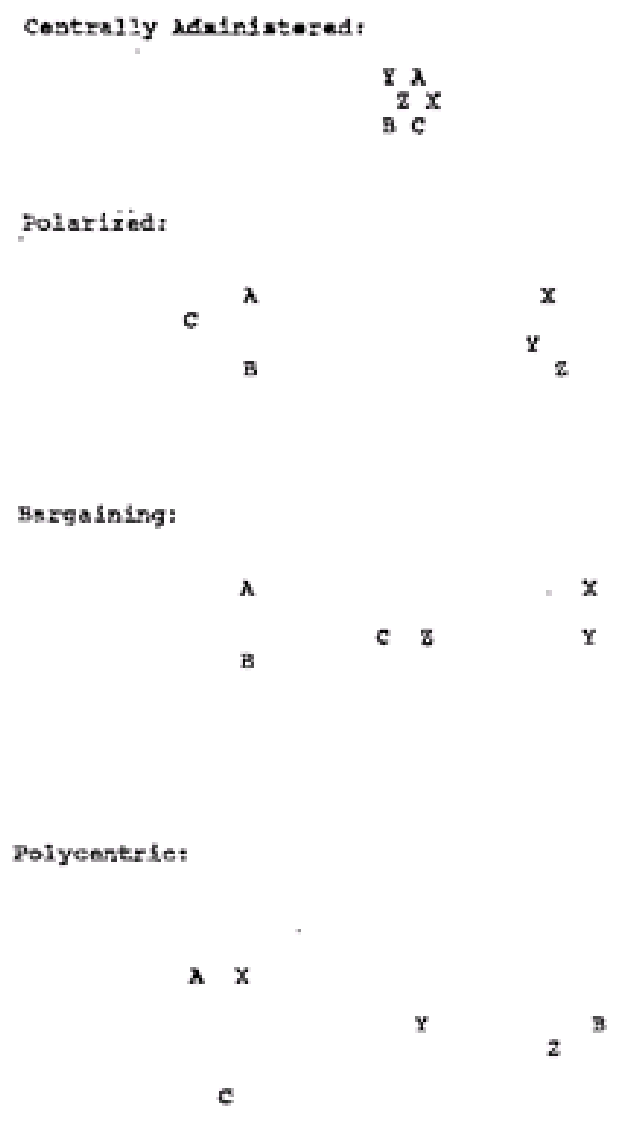

Figure i. Hypothetical oppositional models (Knoke 1990, p. 135). 
Table 1. Descriptive Statistics for Variables

\begin{tabular}{|c|c|c|}
\hline Variable & Mean or Prop & $S D$ \\
\hline \multicolumn{3}{|l|}{ Gender } \\
\hline Male & 0.83 & \\
\hline Female & 0.17 & \\
\hline \multicolumn{3}{|l|}{ Party affiliation } \\
\hline Republican & 0.43 & \\
\hline Democrat & 0.49 & \\
\hline Other & 0.09 & \\
\hline \multicolumn{3}{|l|}{ Lawyer role } \\
\hline Litigation & 0.19 & \\
\hline Legislative advocate & 0.21 & \\
\hline Other role & 0.60 & \\
\hline \multicolumn{3}{|l|}{ Region } \\
\hline D.C. & 0.66 & \\
\hline South & 0.11 & \\
\hline Northeast & 0.13 & \\
\hline West/Midwest & 0.11 & \\
\hline \multicolumn{3}{|l|}{ Law school prestige } \\
\hline Elite & 0.28 & \\
\hline Prestige & 0.34 & \\
\hline Regional & 0.15 & \\
\hline Local & 0.23 & \\
\hline Degree centrality & 7.28 & 5.19 \\
\hline Political contributions & $13,012.43$ & $62,291.21$ \\
\hline Political contributions (logged) & 6.22 & 3.52 \\
\hline$N$ & 47 & \\
\hline
\end{tabular}




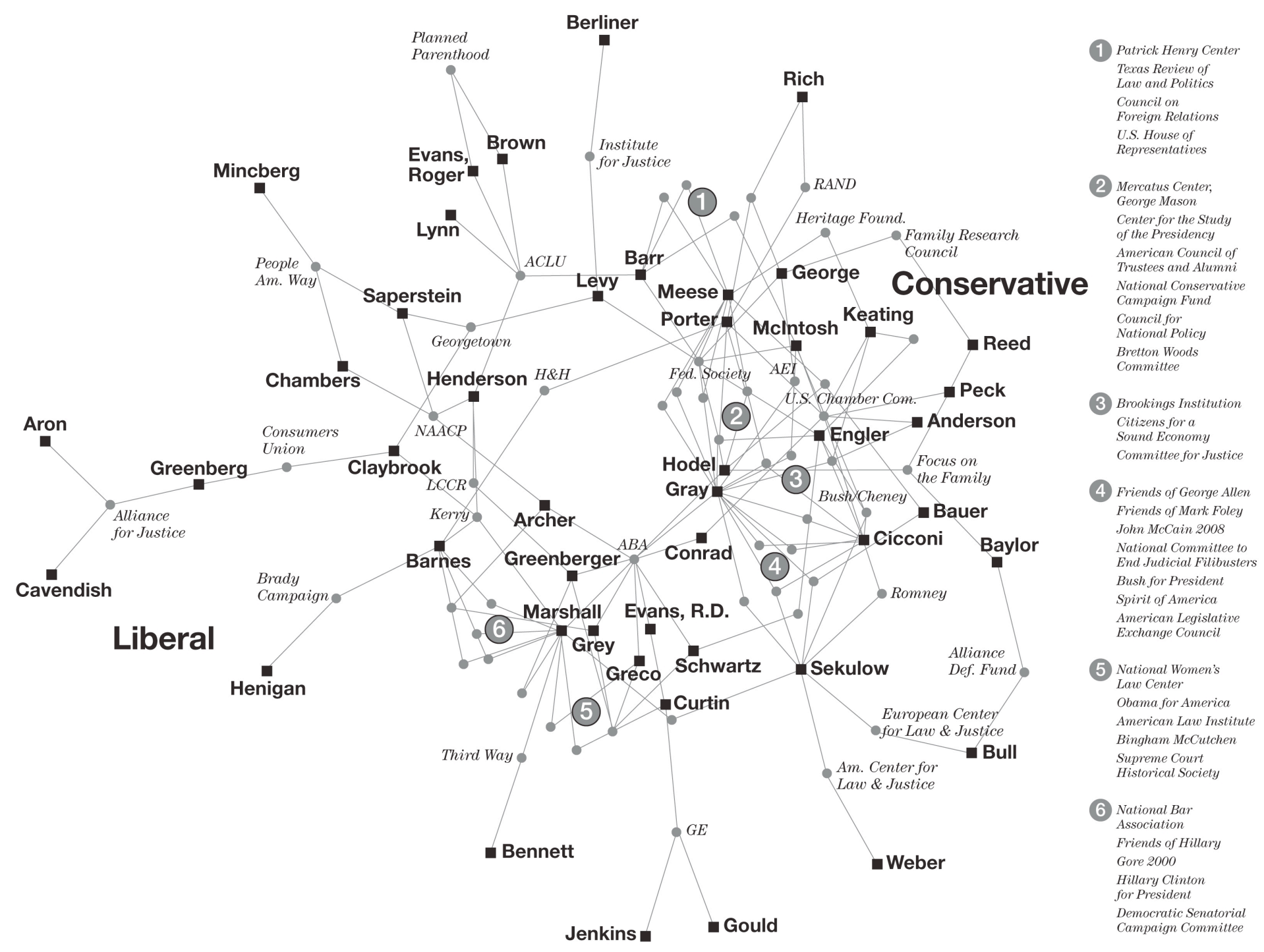

Figure 2: Network Affiliations Between Lawyers and Organizations 


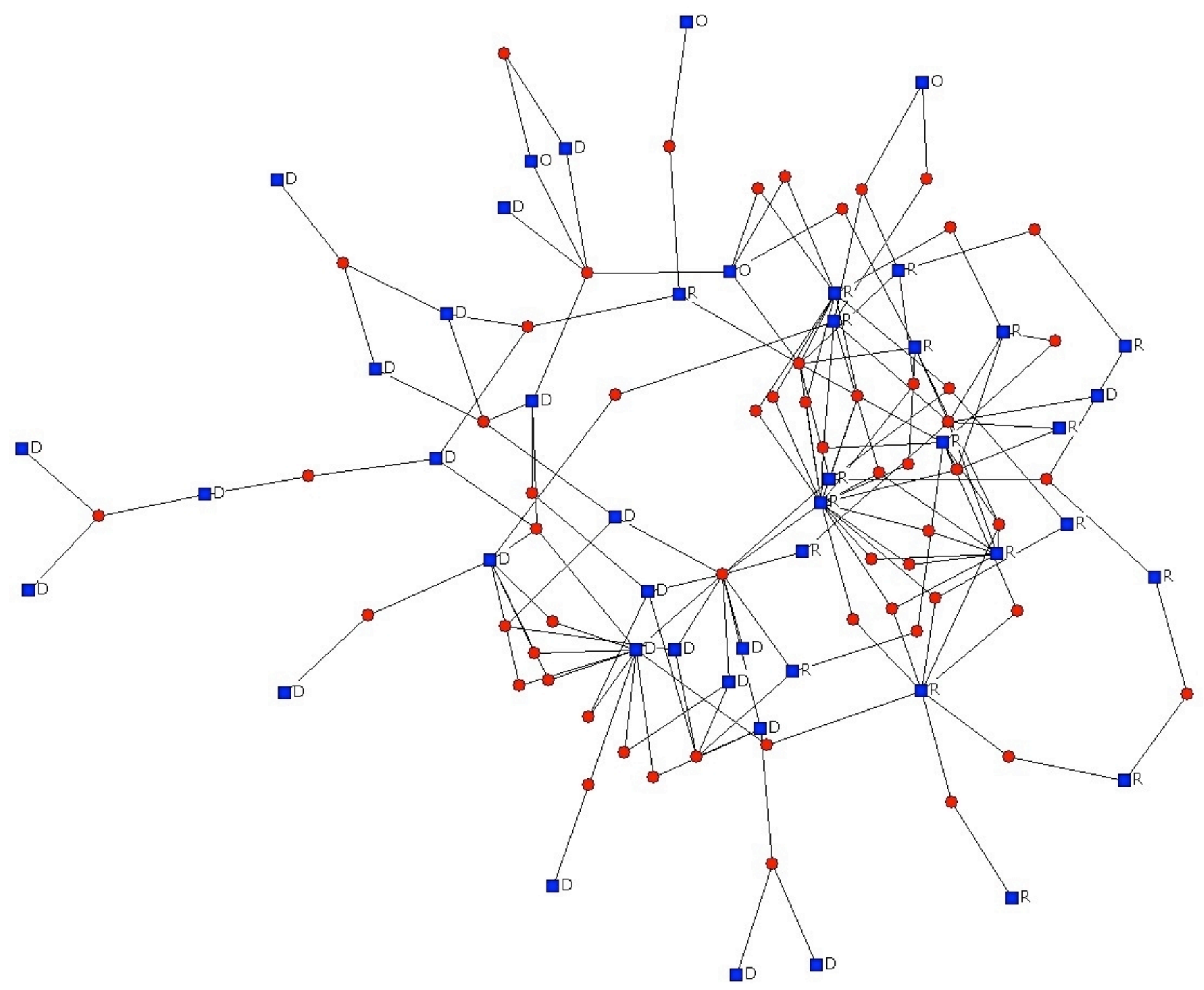

Figure 3: Party Memberships of the Lawyers 


\section{Table 2. Variable Homophily Blockmodels of Tie Density by Categories $(n=2,162)$}

Model

Tie probability

1. Gender

Intercept

0.11

Male

0.06

Female

0.07

$R^{2}$

0.01

Model 2. Party

Intercept

0.09

Republican

$0.27 * * *$

Democrat

$0.11 *$

Other

$R^{2}$

0.08

$0.08 * * *$

Model 3. Lawyer role

Intercept

0.10

Litigator

0.01

Legislative advocate

0.10

Other role

$0.14 * *$

$R^{2}$

0.03

Model 4. Region

Intercept

0.15

D.C.

0.02

South

$-0.15$

Northeast

$-0.02$

West/Midwest

0.05

$R^{2}$

0.00

Model 5. Law school prestige

Intercept

0.17

Elite

$-0.08$

Prestige

$-0.05$

Regional

$-0.07$

Local

0.05

$R^{2}$

0.01

Significance tests based on 5,000 random permutations.

$* \mathrm{p}<=.05 ; * * \mathrm{p}<=.001 ; * * * \mathrm{p}<=.001$ 
Table 3. Bootstrapped Regressions of Centrality and Logged Contributions $(n=47)$

\begin{tabular}{|c|c|c|c|c|}
\hline \multirow{2}{*}{$\begin{array}{l}\text { Variable } \\
\text { Female }\end{array}$} & \multicolumn{2}{|c|}{$\begin{array}{l}\text { Degree } \\
\text { centrality }\end{array}$} & \multicolumn{2}{|c|}{$\frac{\text { Political contrib }}{\underline{2000-2008(10}}$} \\
\hline & & & & \\
\hline Democrat & -3.24 & $*$ & & \\
\hline Other & -3.15 & & & \\
\hline Legislative advocate & 4.27 & & & \\
\hline Other role & 5.96 & $* * *$ & & \\
\hline South & & & & \\
\hline Northeast & & & & \\
\hline West/Midwest & & & & \\
\hline Prestige & & & & \\
\hline Regional & & & & \\
\hline Local & & & & \\
\hline Degree centrality & & & 0.30 & $* * *$ \\
\hline Intercept & 4.67 & & 4.02 & \\
\hline$R^{2}$ & 0.28 & $*$ & 0.20 & $* * *$ \\
\hline
\end{tabular}

Significance tests based on 1,000 random permutations.

$* \mathrm{p}<=.05 ; * * \mathrm{p}<=.001 ; * * * \mathrm{p}<=.001$ 